\title{
REAKTUALISASI AJARAN ISLAM: \\ Studi atas Pemikiran Hukum Munawir Sjadzali
}

\section{Yunahar Ilyas}

Dosen Fakultas Agama Islam Universitas Muhammadiyah Yogyakarta

الملخص

رأى منور شذاليـ انطلاقا من قول ابن قيم الجوزية وأبي يوسفــ أن الرأي (العقل)

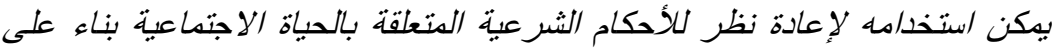

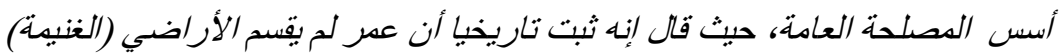

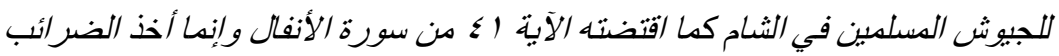

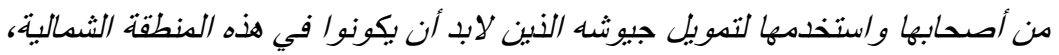

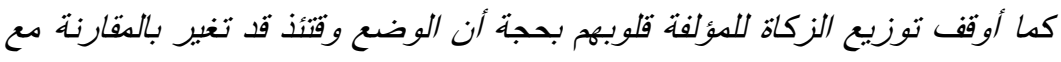

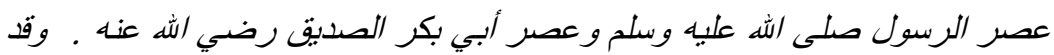

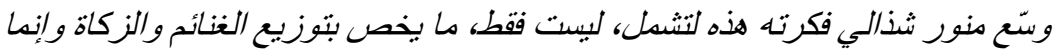

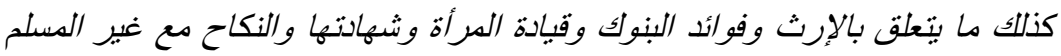

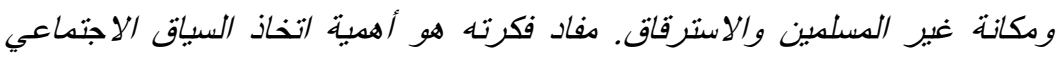

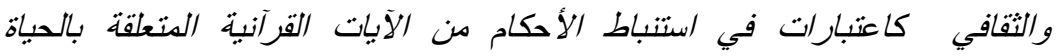
الاجتماعية، وإن كانت النتيجة، في الظاهر، قد تتعارض مع النص.

\section{Abstract}

Referring to Ibn Qayyim al-Jawiziyya and Abü Yüsuf, Munawir Sjadzali says that it is necessary to make use of rational thought based on social context in reasoning and applying a legal rule. It is historical that Caliph Umar has practiced this principle in connection with the case of land- 
Yunahar Ilyas

loot. Instead of taking the land of Syrians as loot, the Caliph 'Umar took tax from the land owners and distributed the money for military. In another chance, Caliph 'Umar stopped giving zakāh to mu'allaf group because there is no longer need to give them zakāh in the current situation, different from what Prophet Mubammad and Caliph Abü Baker have practiced. According to Sjadzali, there are a lot of Islamic legal issues to which an intensive attention and contextualization should be drawn, such as the law of inheritance, zakāh for mu'allaf, bank interest, woman leadership, woman testimony, inter-religious marriage, non Muslim status, slavery, et cetera. The main idea of Sjadzali's thought is the necessity to take social and cultural context of the society into account at comprehending, and then concluding a legal decision from, Quranic verses concerning with social life, though this will led to not apply the extrinsic meaning of those verses.

Keywords: Munawir Sjadzali, re-actualization, social context.

\section{A. Pendahuluan}

Dalam tiga dekade ini, di Indonesia banyak bermunculan istilahistilah yang dipergunakan oleh para pemikir Muslim dan para pengamat sosial-keagamaan Islam untuk menggarisbawahi perlunya meneliti dan mencermati kembali prinsip-prinsip dasar, nilai-nilai dan norma-norma keislaman yang hendak dihidupkan kembali dalam era modernitas. Istilah-istilah itu antara lain adalah reinterpretasi (penafsiran ulang), reaktualisasi (mengangkat dan menghidupkan kembali), reorientasi (memikirkan kembali), revitalisasi (membangkitkan kembali), kontekstualisasi (mempertimbangkan konteks kehidupan sosialbudaya), membumikan Islam, dan istilah-istilah lain yang masih mempunyai kandungan makna yang relatif sama seperti Islam transformatif, Islam intelektual, dan Islam substansial. ${ }^{1}$

Salah satu dari istilah-istilah tersebut yang paling menonjol dan paling banyak menimbulkan kontroversi adalah reaktualisasi, atau tepatnya Reaktualisasi Ajaran Islam dengan tokoh penggagasnya

${ }^{1}$ M. Amin Abdullah, "Telaah Hermeneutis terhadap Masyarakat Muslim Indonesia”, dalam Muhammad Wahyuni Nafis (ed.), Kontekstualisasi Ajaran Islam, 70 Tahun Prof. Dr. Munawir Sjadz̧ali, MA (Jakarta: Paramadina, 1995), hlm. 537. 
Munawir Sjadzali, Menteri Agama Republik Indonesia dua periode (1983-1993). Karena gagasan ini diangkat oleh seorang pejabat tinggi negara yang memiliki banyak forum untuk memasyarakatkan gagasannya,maka segera saja gagasan reaktualisasi itu mendapatkan respons dari umat Islam Indonesia, terutama dari kalangan ulama dan pemikir Muslim. Tidak ketinggalan juga tanggapan dari masyarakat awam. Popularitas gagasan ini-terlepas dari pro dan kontramengalahkan gagasan pembaharuan pemikiran Islam lainnya.

Artikel ini ditulis bukanlah dengan maksud ikut menanggapi substansi dan argumentasi gagasan itu sendiri, tapi berusaha mengungkap latar belakang kenapa gagasan reaktualisasi itu muncul dan bagaimana respons para ulama dan pemikir Muslim terhadap gagasan itu. Sedapat mungkin juga dilihat sejauh mana pengaruh gagasan tersebut terhadap pemikiran Islam di Indonesia. Pendekatan yang digunakan adalah pendekatan historis, bukan teologis atau fikih, dengan demikian pembaca tidak akan menemukan analisis apalagi penilaian terhadap kebenaran pemikiran itu sendiri.

\section{B. Siapa Munawir Sjadzali}

Sebelum diangkat oleh Presiden Soeharto sebagai Menteri Agama dalam Kabinet Pembangunan IV (1983), Munawir Sjadzali tidak banyak dikenal oleh masyarakat, apalagi dalam bidang pemikiran Islam. Hal itu dapat dimaklumi karena dalam kariernya di Departemen Luar Negeri (1950-19830), Munawir lebih banyak berada di luar negeri dalam berbagai jabatan diplomatik, mulai dari Sekretaris III Kedutaan Besar Republik Indonesia di Washington D.C. (1956-1959), Sekretaris I KBRI di Colombo Srilangka (1963-1966), kemudian Kuasa Usaha Sementara KBRI yang sama (1966-1968), Minister Councelor KBRI London (19701975) sampai menjadi Duta Besar RI di KBRI Kuwait, merangkap Duta Besar RI non resident untuk Uni Emirat Arab (UEA), Qatar dan Bahrain (1976-1980). Total dari 33 tahun berkarir di Deplu, Munawir menghabiskan 17 tahun di luar negeri, sedangkan di dalam negeri Munawir menduduki berbagai jabatan di Deplu mulai dari staf seksi Arab/Timur Tengah (1950) sampai Dirjen Politik (1980-1983). Praktis Munawir tidak pernah terjun dalam bidang yang menyebabkan dia bisa dikenal luas oleh masyarakat. 
Munawir Sjadzali dilahirkan di Klaten, Jawa Tengah, 7 November 1925 dari pasangan Abu Aswad Hasan Sjadzali bin Tohari (setelah menikah diberi nama tua Mughaffir) dan Tas'iyyah binti Badruddin. Ayah Munawir adalah seorang Kyai di kampungnya yang secara formal menjabat Kepala Madrasah Bi'tsah al-Muslimin (tingkat Ibtidaiyah) di Karanganom Klaten. Nama Sjadzali di belakang nama ayahnya karena memang beliau seorang pengikut Tarekat Syadzaliyah. Itu pulalah sebabnya di belakang nama anaknya juga ditambah Sjadzali.

Pendidikan agama diperoleh Munawir pertama dari orang tuanya sendiri, dan kedua dari pendidikan formal di Madrasah Ibtidaiyah (5 tahun) di Karang Anom, Tsanawiyah (1 tahun) di Madrasah Al-Islam Solo, kemudian Pondok Pesantren Manba'ul 'Ulum Solo (5 tahun).

Setelah tamat Manba'ul 'Ulum tahun 1943, Munawir sempat jadi guru Sekolah Dasar Islam Ungaran, Jawa Tengah satu tahun, kemudian ikut perjuangan mempertahankan kemerdekaan di daerah Jawa Tengah sampai tahun 1949. Seperti disebutkan di atas tahun 1950 Munawir mulai berkarier di Departemen Luar Negeri Jakarta. ${ }^{2}$

Selama berkarier di Deplu, Munawir sempat mengikuti Kursus Diplomatik dan Konsuler Angkatan II (1951) selama 10 bulan, dan pendidikan ilmu politik selama satu tahun di University College of South West of England, Exeter (1953). Waktu bertugas di Amerika, Munawir menyempatkan mengikuti kuliah pascasarjana di Universitas Georgetown dalam bidang Hubungan Internasional dan mendapat Master tahun 1959 dengan tesis: Indonesia's Muslim Political Parties and Their Political Concept. ${ }^{3}$

${ }^{2}$ Diringkas dari Munawir Sjadzali, "Dari Lembah Kemiskinan” dalam Muhammad Wahyuni Nafis dkk (editor), Kontekstualisasi Ajaran Islam, 70 tahun Prof. Dr. H. Munawir Sjadzali, MA (Jakarta: Paramadina, 1995), hlm. 1-115. Baca juga Bahtiar Effendy dkk, "Munawir Sjadzali, M.A; Pencarian Ketegangan Ideologis", dimuat dalam Azyumardi Azra dan Saiful Umam. Menteri-Menteri Agama RI Biografi Sosial-Politik, cet. I, (Jakarta : INIS, 1998), hlm. 372-384.

${ }^{3}$ Saat menyelesaikan studi masternya inilah terjadi "keajaiban", apa yang kemudian dianggapnya sebagai blessing in disguise. Pada semester tertentu, karena ingin selesai tepat pada waktunya, ia nekad mengambil tiga matakuliah, padahal semester sebelumnya ia mendapatkan nilai B dan C dari dua matakuliah yang diambil. Belum lagi, berbagai kesibukan kantor yang mesti diselesaikan. Menurut logika, dua matakuliah saja jatuh satu, bagaimana dengan tiga matakuliah. Pada pertengahan semester Munawir jatuh 
Karya tulis Munawir yang pertama terbit tahun 1950 berjudul Mungkinkah Negara Indonesia Bersendikan Islam (80 halaman). Buku itu dicetak 5000 eksemplar dan dalam 4 bulan habis. Lewat buku itulah dia dapat berkenalan dengan Bung Hatta, Wakil Presiden RI pertama (lewat penyalur bukunya, Zein Jambek, ipar Hatta, direktur toko buku Tintamas Jakarta). Atas jasa baik Hatta, Munawir diterima jadi pegawai negeri di Deplu. Karya Munawir lainnya adalah Islam dan Tata Negara, Ajaran, Sejarah dan Pemikiran, "Reaktualisasi Ajaran Islam" dalam Polemike Reaktualisasi Ajaran Islam, dan "Dari Lembah Kemiskinan" dalam Kontekstualisasi Ajaran Islam, 70 Tabun Prof. Dr. H. Munawir Sjadzali, $M A$.

Atas permintaan Dekan Fakultas Pascasarjana IAIN (sekarang UIN) Syarif Hidayatullah Jakarta, sejak tahun 1988 Munawir mengajar mata kuliah Islam dan Tata Negara di Pascasarjana IAIN Syarif Hidayatullah Jakarta. Begitu pula atas permintaan Dekan Fakultas Syari'ah IAIN Sunan Kalijaga (pada saat dipimpin oleh Drs. H. Zarkasyi Abd. Salam) Munawir memberikan ceramah Islam dan Tata Negara di IAIN Sunan Kalijaga (sekarang UIN Sunan Kalijaga). Pada tahun 1994 IAIN Syarif Hidayatullah menganugerahi Munawir Doktor Honoris Causa. Di samping itu beliau juga pernah menjadi Lektor Tamu pada Institute of Islamic Studies McGill University, Canada (Maret-Mei 1994), dan Universitas Leiden, Belanda (April 1995).

\section{Perjalanan Gagasan Reaktualisasi}

Menurut Bustanil Arifin, mantan Ketua Muda Mahkamah Agung untuk urusan lingkungan Peradilan Agama, gagasan yang kemudian hari dikenal sebagai gagasan reaktualisasi hukum Islam, pertama kali

sakit dan oleh seorang dokter dinyatakan terkena sakit kuning (hepatitis), sehingga ia diperintahkan untuk istirahat total selama tujuh minggu, tidak boleh bekerja dan tidak diizinkan kuliah serta dilarang makan makanan yang berlemak. Namun, ia menggunakan waktu selama tujuh minggu di kamar tidur bergumul dengan buku-buku yang dipinjam dari perpustakaan, tanpa harus memikirkan pekerjaan KBRI dan kuliah. Akhirnya, pada ujian akhir semester, dari tiga matakuliah, dua di antaranya mendapat nilai A- dan $\mathrm{B}+$, yang disadarinya kemudian adalah Tuhan membikinnya sakit agar dapat konsentrasi belajar, blessing in disguise. Akhirnya ia berhasil meraih gelar masternya di Amerika Serikat. Selengkapnya baca Iqbal Sentosa. "Prof. Dr. Munawir Sjadzali, M.A.: Hidup yang tak Terbayangkan”, PERTA, No. 2/Vol. III/2000, hlm. 62-63. 
dikemukakan oleh Munawir pada tanggal 15 April 1985 (dua tahun setelah menjabat Menteri Agama R.I.). Waktu itu Munawir memberikan kata sambutan dalam pertemuan Panitia Kompilasi Hukum Islam bertempat di gedung Mahkamah Agung. Hadir dalam kesempatan itu segenap anggota panitia, para hakim agung, Ketua Mahkamah Agung Ali Said, dan K.H. Ibrahim Hosen dari Majelis Ulama Indonesia. Sementara itu Bustanil Arifin sendiri hadir sebagai Pimpinan Proyek Kompilasi Hukum Islam. ${ }^{4}$

Setelah itu Munawir menyampaikan gagasannya secara gencar dalam berbagai kesempatan, antara lain dalam (1) Seminar Hukum Islam yang diselenggarakan oleh Institut Agama Islam Negeri Imam Bonjol Padang; (2) Forum Bahsul Masail Syuriah Nahdhatul Ulama Jawa Timur di Tambak Beras, Jombang; (3) Seminar Kompilasi Hukum Islam yang diselenggarakan oleh Pimpinan Pusat Muhammadiyah di Yogyakarta ${ }^{5}$; (4) Penataran Pimpinan Pemuda Anshor Tingkat Propinsi Seluruh Indonesia di Malang; (5) Latihan Kader Tarjih Muhammadiyah di Yogyakarta (dua kali) ${ }^{6}$; (6) Ceramah di hadapan Mahasiswa Indonesia di Kairo; (7) Forum Kodifikasi Hukum Islam yang diselenggarakan oleh South East Asian Shariah Association di Kolombo, Srilanka; (8) Jamuan makan malam yang diselenggarakan oleh Menteri Pengajaran Malaysia, Anwar Ibrahim di Kuala Lumpur; juga disampaikan di (9) Pengajian perdana Yayasan Wakaf Paramadina, 28 November 1986 di Jakarta. $^{7}$

Segera saja pemikiran Munawir tersebut menjadi topik pembicaraan di berbagai forum, baik yang ilmiah seperti seminar dan diskusi, maupun forum-forum dakwah seperti ceramah dan khutbah. Tidak sedikit pula yang menghujatnya lewat surat pembaca berbagai surat kabar. Menurut Munawir, reaksi-reaksi yang tidak atau kurang bersahabat itu baru muncul setelah gagasan itu disampaikan dalam pengajian Paramadina. Padahal dalam forum-forum lain, katanya,

${ }^{4}$ Bustanil Arifin, "Munawir Sjadzali dan Alur Pemikirannya", dalam Munawir Sjadzali, Ijtihad Kemanusiaan (Jakarta:Paramadina, 1997), hlm. xix.

${ }^{5}$ Dalam Seminar ini penulis ikut sebagai panitia (notulis).

${ }^{6}$ Dalam LKT ini penulis ikut sebagai peserta.

${ }^{7}$ Munawir Sjadzali, "Reaktualisasi Ajaran Islam”, dalam Iqbal Abdurrauf Saimima, Polemik Reaktualisasi Ajaran Islam (Jakarta: Pustaka Panjimas, 1988), hlm.1. 
reaksinya lebih bersahabat. ${ }^{8}$ Tampaknya Munawir ingin mengatakan bahwa sikap kontra terhadap gagasannya lebih banyak disebabkan oleh faktor Paramadinanya daripada isi gagasannya sendiri. Seperti diketahui sejak lama Nurcholish Madjid, di samping memiliki pendukung fanatik, juga menghadapi penentang fanatik, terutama sejak ide sekularisasinya diperdebatkan publik. ${ }^{9}$

Sebenarnya dapat dipahami, kenapa reaksi keras -atau menurut istilah Munawir tidak bersahabat-tidak muncul dalam forum-forum yang dihadirinya, karena posisinya sebagai Menteri Agama dan biasanya diundang untuk memberikan kata sambutan, menyebabkan para audience tidak punya kesempatan untuk menanggapi, atau kalaupun dalam kesempatan, secara psikologis tidak enak menanggapi langsung di hadapan yang bersangkutan. Budaya Indonesia tidak menganggap terpuji berbeda pendapat, apalagi berdebat dengan tamu yang dinilai mempunyai kedudukan lebih terhormat seperti seorang menteri. Biasanya setelah sang Menteri pergi para pendengar akan menanggapinya secara spontan dalam forum-forum kecil. ${ }^{10}$

Di samping dua faktor di atas, ada kemungkinan telah terjadi kesalahfahaman terhadap ide Munawir karena orang tidak mengikutinya atau mendengarnya secara utuh. Peliputan oleh media massa biasanya tidak mengungkap secara utuh. Oleh sebab itu majalah Panji Masyarakat mengundang Munawir untuk menuliskan idenya secara utuh biar dapat dibaca dan ditanggapi oleh yang berkompeten. Demikianlah, Panjimas No. 543, tanggal 21 Juni 1987 memuat tulisan Munawir dengan judul "Reaktualisasi Ajaran Islam". Tulisan ini kemudian dapat tanggapan secara tertulis oleh para ulama dan cendekiawan yang kemudian dibukukan dan diterbitkan oleh Pustaka Panjimas (1988) dengan judul Polemike Reaktualisasi Ajaran Islam. Ada 13 tanggapan yang dipublikasikan, masing-masing dari Nurcholish Madjid, Syafruddin

${ }^{8}$ Ibid.

${ }^{9}$ Karya-karya yang membicarakan Nurcholish Madjid dapat dibaca seperti, Jalaluddin Rakhmat, et. Al. Tharikat Nurcholishy Jejak Pemikiran dan Pembaharuan sampai Guru Bangsa, cet. I (Yogyakarta : Pustaka Pelajar, 2002), Adian Husaini. Nurcholish Madjid Kontroversi Kematian dan Pemikirannya, cet. I (Jakarta : Khairul Bayan, Press, 2005), dan Charles Kurzman. Liberal Islam, cet. I (New York : Oxford University Press, 1998).

${ }^{10}$ Penulis dapat mengatakan demikian, karena telah menghadiri empat forum saat Munawir menyampaikan ide-ide reaktualisasinya. 
Prawiranegara, Jalaluddin Rakhmat, Rifyal Ka'bah, Ali Darokah, Ali Yafie, Ahmad Azhar Basyir, Kamaluddin Marzuki, M. Yahya Harahap, Peunoh Dali, Aminullah HM, dan Masdar F. Mas'udi. Buku tersebut diberi Pendahuluan oleh Syu'bah Asa. ${ }^{11}$

Tujuh tahun kemudian (1995), Munawir menuliskan kembali gagasannya (dengan sedikit tambahan penjelasan) dalam buku Kontekstualisasi Ajaran Islam, 70 tabun Prof. Dr. H. Munawir Sjadzali, $M A$ yang diterbitkan oleh Paramadina bekerjasama dengan Ikatan Persaudaraan Haji Indonesia. Walaupun ada sedikit tambahan dari tulisannya terdahulu, dapat dikatakan sama sekali tidak ada yang baru dikemukakannya dalam tulisan tersebut. Dalam buku yang terdiri dari enam bagian tersebut, dimuat satu bagian yang berbicara khusus tentang ide reaktualisasi Munawir (hlm. 249-332). Dalam bagian tersebut diturunkan tulisan Ibrahim Hosein, Satria Efendi M. Zein, Ali Yafie, dan Atho Mudzhar.

Bulan Juni 1997, Paramadina kembali menerbitkan buku kecil karya Munawir dengan judul Ijtihad Kemanusiaan. Kali ini gagasan Reaktualisasi atau Kontekstualisasi Munawir diuraikan secara lebih detail dari dua tulisan sebelumnya. Baik dalam Polemik, maupun dalam Ijtibad Kemanusiaan, Munawir tidak menanggapi secara langsung keberatan-keberatan yang telah dikemukakan oleh para penanggapnya sejak sembilan tahun yang lalu. Padahal sebaiknya Munawir memberikan jawaban atas keberatan-keberatan yang diberikan, baik menyangkut substansi, argumentasi, maupun metodologi yang digunakan.

\section{Garis Besar Pemikiran Munawir ${ }^{12}$}

Seperti sudah diungkap di atas, pemikiran reaktualisasi atau kontekstualisasi Munawir dipublikasikannya secara tertulis tiga kali

\footnotetext{
Islam, hlm.23.

${ }^{12}$ Selama menjadi Menteri Agama, Munawir Sjadzali selain menggagas tentang Reaktualisasi, juga berhasil melakukan berbagai terobosan, antara lain: (1) Pembenahan IAIN, ia bersama Menteri Pendidikan dan Kebudayaan, Prof. Dr. Nugroho Notosusanto, dan Menteri Pendayagunaan Aparatur Negara, Prof. Dr. Saleh Afif, berhasil menerbitkan Peraturan Pemerintah Nomor 33 Tahun 1985 yang memberikan status,
}

${ }^{11}$ Selengkapnya baca Iqbal Abdurrauf Saimima, Polemik Reaktualisasi Ajaran 
dalam rentang waktu yang berbeda, pertama tahun 1988 (Reaktualisasi Ajaran Islam), kedua tahun 1995 (Gagasan Reaktualisasi Ajaran Islam), dan ketiga tahun 1997 (Ijtibad Kemanusiaan). Penulis akan sarikan ide Munawir dari masing-masing tulisan tersebut.

Dalam tulisan pertama, Munawir mengungkapkan bahwa dia merasa resah dengan adanya sikap mendua umat Islam Indonesia dalam beragama. Di satu sisi tetap mempertahankan keyakinan tentang sesuatu, tapi di sisi lain tidak mengamalkannya. Dia mengemukakan dua contoh, yaitu tentang bunga bank dan pembagian warisan.

Menurut Munawir, umat Islam meyakini bahwa bunga bank adalah riba, oleh sebab itu haram, tapi dalam prakteknya umat tetap menggunakan jasa bank dan hidup dari bunga deposito yang diperoleh. Begitu juga tentang pembagian warisan, umat Islam tetap meyakini bahwa, berdasarkan surat al-Nisā' ayat 11, anak laki-laki mendapat warisan dua bagian anak perempuan. Tapi ketentuan ini sudah lama ditinggalkan dalam prakteknya. Kesimpulan ini diambil Munawir setelah mendapat laporan dari para Hakim Agama di Sulawesi Selatan dan Kalimatan Selatan (dua daerah yang dikenal kuat keislamannya), bahwa meskipun pengadilan agama sudah mengeluarkan fatwa waris, mereka memindahkan perkaranya ke pengadilan negeri.

Di samping penolakan langsung seperti kasus di dua propinsi itu, Munawir juga menengarai banyak umat, bukan hanya kalangan awam, tapi juga dari kalangan ulamanya, yang menolak formula 2:1 tersebut secara pre-emptiv dengan cara membagi habis warisan dengan wasiat wajibah atau menghibahkannya sebelum yang bersangkutan meninggal dunia. Dalam wasiat wajib atau hibah itu, anak perempuan diberi bagian sama dengan anak laki-laki. Dalam hal ini Munawir juga punya pengalaman pribadi sendiri, bagaimana seorang kyai menasehatinya untuk membuat wasiat wajib tatkala dia berkonsultasi tentang pembagian waris untuk anak-anaknya nanti. Tatkala dia masih

fasilitas, dan perlakuan kepada 14 IAIN yang sama dengan Perguruan Tinggi Negeri yang dikelola Departemen Pendidikan dan Kebudayaan, (2) Menyempurnakan SKB tiga Menteri 1975 dengan mengadakan pilot project Madrasah Aliyah Program Khusus, (3) Melanjutkan proyek pengiriman mahasiswa S2 ke Barat yang telah dirintis oleh Prof. Dr. H.A. Mukti Ali, (4) Pembenahan Undang-undang Peradilan Agama yang melahirkan UU No. 7 Tahun 1989, dan (5) Pembenahan Proyek Kompilasi Hukum Islam. 
hidup, anak laki-laki sudah mengeluarkan biaya jauh lebih besar dibandingkan dengan anak perempuan, apakah adil kalau nanti anak perempuan dapat warisan lebih kecil dari saudara laki-lakinya.

Berdasarkan latar belakang di atas, Munawir kemudian mengajukan ide untuk melakukan modifikasi terhadap ketentuan tersebut yang kemudian diistilahkannya dengan reaktualisasi. Tetapi pertanyaannya, apakah reaktualisasi tersebut boleh dilakukan? Bukankah ketentuan hukum tersebut berdasarkan nas yang oleh para ulama dinilai qath'? Menurut Munawir dalam aspek kemasyarakatan, nas yang qat i $i$ sekali pun dapat dimodifikasi dengan alasan bukankah dalam sejarahnya juga ada beberapa ayat yang di-mansükh oleh ayat lain. Tentang naskh ini Munawir mengutip Musțafā al-Marāghy sebagai berikut:

Sesungguhnya hukum-hukum itu diundangkan untuk kepentingan manusia, dan kepentingan manusia dapat berbeda karena perbedaan waktu dan tempat. Apabila suatu hukum diundangkan pada waktu dirasakan kebutuhan akan adanya hukum itu, kemudian kebutuhan itu tidak ada lagi, maka tindakan yang bijaksana adalah menghapuskan hukum itu dan menggantikannya dengan hukum (lain) yang lebih sesuai dengan waktu terakhir. ${ }^{13}$

Peninjauan kembali terhadap aturan hukum dalam aspek kemasyarakatan dapat dilakukan dengan penggunaan penalaran intelektual, dengan kepentingan masyarakat sebagai dasar pertimbangan atau tolak ukur utama. Sebagai rujukan pendapatnya itu, Munawir mengutip pendapat Ibn Qayyim al-Jauziyah yang mengatakan bahwa perubahan dan perbedaan fatwa atau opini hukum dapat terjadi karena perbedaan waktu, tempat (lingkungan), situasi, tujuan dan adat istiadat; dan pendapat Abu Yusuf yang berpendirian bahwa nas sekali pun kalau dasarnya adat, dan adat tersebut kemudian telah berubah, maka gugur pula hukum yang terkandung dalam nas itu. ${ }^{14}$

Untuk mendukung gagasannya itu Munawir mengemukakan fakta historis bahwa Umar pernah melakukannya dalam kasus rampasan perang yang sudah diatur oleh surat al-Anfăl: 41. Umar tidak mau

\footnotetext{
${ }^{13}$ Iqbal Abdurrauf Saimima, Polemik, hlm. 7.

${ }^{14}$ Ibid., hlm. 8.
} 
membagi-bagi tanah rampasan perang di daerah Syam untuk para prajurit, tapi hanya menarik pajak dari pemiliknya, dan pajak itu digunakan untuk membiayai angkatan bersenjata yang harus tetap berada di posnya di daerah utara. ${ }^{15}$

Tulisan kedua hampir keseluruhannya sama dengan tulisan pertama, kecuali ada tambahan contoh kasus ijtihad Umar yang dinilai berbeda dengan nas qat $i$ yaitu tentang zakat untuk para muallaf sebagaimana yang diatur oleh surat al-Tawbah: 60. Umar menghentikan pemberian zakat kepada mu'allaf dengan alasan situasi telah berubah dari zaman Nabi dan Abu Bakar, sehingga pemberian zakat kepada mereka tidak dianggap perlu lagi. Dalam tulisan kedua ini Munawir juga menyinggung tentang keheranannya menemukan kenyataan justru kalangan modernis yang memberikan reaksi keras menolak gagasannya, padahal golongan tradisional (NU) dapat menerimanya dengan baik. ${ }^{16}$

Dalam tulisan terakhir, Ijtihad Kemanusiaan, Munawir memperluas kasus-kasus yang perlu dilakukan kontekstualisasi, tidak hanya soal warisan anak perempuan, zakat untuk muallaf, bunga bank, tapi juga tentang kepemimpinan wanita (Q.S. al-Nisāa, 4:34), kesaksian wanita (Q.S. al-Baqarah, 2:282), hak wanita muslimah kawin dengan laki-laki non muslim, kedudukan warga non Muslim, dan kasus perbudakan. ${ }^{17}$

Inti dari gagasan yang dikemukakan Munawir adalah tentang perlunya mempertimbangkan konteks kehidupan sosial-budaya masyarakat dalam memahami dan membuat kesimpulan hukum dari ayat-ayat Al-Qur'an dalam bidang kemasyarakatan, walau pun untuk itu kelihatannya tidak mengamalkan makna lahir dari teks tersebut. Sebagaimana Umar telah melakukannya untuk kasus rampasan perang dan muallaf, maka di Indonesia pun, seru Munawir, harus berani melakukan hal yang sama. Tanpa melakukan kontekstualisasi tersebut, ajaran Al-Qur'an akan ketinggalan zaman, atau kehilangan relevansinya untuk masa kini, atau ajaran tersebut menjadi mati (tidak dapat diamalkan).

${ }^{15}$ Untuk mengetahui ijtihad-ijtihad Umar bin Khattab selengkapnya dapat dibaca karya Muḥammad Baltājy, Manhaj 'Umar ibn al-Khaț̣āb fil'-Tasyri . Karya ini merupakan disertasi yang dipertahankan di Universitas Al-Azhar Mesir.

${ }^{16} \mathrm{Ibid}, \mathrm{hlm} .96$.

${ }^{17}$ Penjelasan selengkapnya baca Munawir Sjadzali. Ijtihad Kemanusiaan, hlm. 24. 
Demikianlah garis besar pemikiran reaktualisasi ajaran Islam yang dikemukakan oleh Munawir Sjadzali.

\section{E. Respons terhadap Reaktualisasi}

Seperti yang sudah disebutkan di atas, gagasan reaktualisasi Munawir mendapatkan tanggapan yang cukup luas dari masyarakat ilmiah Indonesia, baik yang pro maupun yang kontra. Dalam buku Polemik Reaktualisasi Ajaran Islam, dimuat 12 tanggapan dari kalangan ulama dan cendekiawan, yaitu: K.H. Ahmad Azhar Basyir, MA, "Reaktualisasi, Pendekatan Sosiologis tidak Selalu Relevan"; Prof. K. H. Ali Yafie, "Antara Ketentuan dan Kenyataan?"; K. H. Ali Darokah, "Reaktualisasi Mencari Kebenaran, Ikhtiar yang Wajar"; Dr. Nurcholish Madjid, "Pertimbangan Kemaslahatan dalam Menangkap Makna dan Semangat Ketentuan Keagamaan: Kasus Ijtihad Umar ibn Khattab"; Mr. Syafruddin Prawiranegara, "Reinterpretasi Sebagai Dasar Reaktualisasi Ajaran-ajaran Islam"; Drs. Jalaluddin Rakhmat, M.Sc., "Kontroversi Sekitar Ijtihad Umar"; R.A.; Rifyal Ka'bah, MA, Bawalah kepada Kami Al-Qur'an yang Lain atau Gantilah"; Kamaluddin Marzuki, MA, "Jangan Sampai Energi Terbuang Percuma”; M. Yahya Harahap SH, "Praktek Hukum Waris tidak Pantas Membuat Generalisasi"; Dr. H. Peunoh Dali, "Menelusuri Pemikiran Maslahat dalam Hukum Islam"; Aminullah HM, "Sekitar Formulasi Hukum Kewarisan dalam Semangat Reaktualisasi Ajaran Islam"; Drs. Masdar F. Mas'udi, "Memahami Ajaran Suci dengan Pendekatan Transformasi".

Dalam buku Kontekstualisi Ajaran Islam dimuat empat tanggapan masing-masing dari Prof. K.H. Ibrahim Hosein, "Beberapa Catatan tentang Reaktualisasi Hukum Islam"; Dr. H. Satria Effendi M. Zein, "Munawir Sjadzali dan Reaktualisasi Hukum Islam di Indonesia"; Dr. Atho Mudzhar, "Letak Gagasan Munawir Sjadzali dalam Konteks Reaktualisasi Hukum Islam di Dunia Islam"; dan dari K. H. Ali Yafie, "Reaktualisasi Hukum Islam di Indonesia". ${ }^{18}$

${ }^{18}$ Sengaja gelar-gelar akademis dan non akademis penulis tulis di depan atau belakang nama-nama para penanggap sekadar untuk menggambarkan latar belakang pendidikan mereka. 
Dari segi semangat, para penanggap tampaknya dapat menyetujui usaha-usaha reaktualisasi baik, yang dilakukan oleh Munawir maupun pemikir lainnya. Hanya saja sebagian dari mereka berbeda pendapat dalam metodologi yang digunakan dan juga dalam menilai kasus-kasus yang dikemukakan. Ibrahim Hosein, misalnya, memberikan catatan tentang maslahat yang didahulukan dari nas jika terjadi pertentangan antara keduanya. Ibrahim Hosein mempersoalkan apakah dapat terjadi pertentangan antara nas dan maslahat, sebab dalam nas itu sendiri sudah terkandung nilai kemaslahatan. Dan juga, apakah benar tidak ada pertentangan dalam maslahat itu sendiri? ${ }^{19}$

Ibrahim Hosein juga menjelaskan pendapat Abu Yusuf yang dikutip oleh Munawir yang menyatakan bahwa nas sekalipun, kalau dahulu dasarnya adat, dan adat tersebut kemudian telah berubah, maka gugur pula hukum yang terkandung dalam nas itu. Menurut Ibrahim Hosein, adat yang dijadikan sendi hukum yang kemudian berubah tersebut tidaklah berkenaan dengan substansi hukum melainkan dengan penjelasan dan penerapannya. ${ }^{20}$

Karena Munawir berargumentasi dengan ijtihad Umar, maka Jalaluddin Rakhmat menguraikan lima pandangan tentang ijtihad Umar, yaitu (1) Ijtihad Umar tidak meninggalkan nas, apalagi mengganti atau menghapus ketentuannya; (2) Ijtihad Umar memang meninggalkan æăăhir nas. Karena ia berpegang kepada ruh nas, atau maqāsid al-aḅkām alshar'iyyah; (3) Ijtihad Umar berkenaan dengan masalah-masalah qat'iyyah yang bukan bidang ijtihad; tetapi ini diperbolehkan khusus untuk Umar; (4) Ijtihad Umar telah meninggalkan nas yang șarhh, tetapi sebagaimana berlaku pada setiap mujtahid, ijtihadnya tetap memperoleh ganjaran; (5) Ijtihad Umar memang banyak melanggar nas yang qat $i$, tetapi itu dilakukan Umar karena kekurangan informasi yang diterimanya untuk persoalan yang bersangkutan. ${ }^{21}$

Sementara itu, Syafruddin Prawiranegara menjelaskan tentang makna keadilan dalam warisan, dan juga tentang status hukum waris yang masuk kategori voluntary law (hukum yang berlaku kalau yang berkepentingan tidak mempergunakan alternatif-alternatif lain yang

${ }^{19}$ Muhammad Wahyuni Nafis, Kontekstualisasi, hlm. 258-260.

${ }^{20}$ Ibid., hlm. 264.

${ }^{21}$ Iqbal Abdurrauf Saimima, Polemik, hlm. 45. 
tersedia), bukan compulsary law (hukum yang berlaku secara mutlak). Para ahli waris dapat memusyawarahkan terlebih dahulu sebelum melakukan pembagian waris jika memang ada kasus yang perlu jadi perhatian seperti yang dikemukakan oleh Munawir. ${ }^{22}$

Demikianlah, tentu tidak tepat kalau dalam artikel yang sederhana dan singkat ini dipaparkan semua tanggapan-tanggapan tersebut. Satu hal yang perlu dicatat, karena penggagas adalah seorang menteri atau mantan menteri, maka tampak sekali para penentang atau pengkritiknya berhati-hati menyampaikan tanggapannya.

Di samping tanggapan yang ada dalam dua buku yang dikutip di atas, banyak tanggapan disampaikan dalam majalah-majalah, korankoran atau media lainnya. Sayangnya untuk keperluan artikel ini, penulis belum dapat menelitinya.

\section{F. Posisi Pemikiran Reaktualisasi Munawir dalam Peta Pembaruan Pemikiran Islam di Indonesia}

Menurut pengamatan Fazlur Rahman, sejak abad ke-18 sampai dengan abad ke-20, gerakan pembaharuan pemikiran Islam dapat dikelompokkan kepada empat tipologi: (1) Revivalisme Pramodernis, yang muncul pada abad ke-18 dan 19 di Arabia (Wahabiah), India (Syah Waliullah) dan Afrika (Sanusiah). Gerakan ini ingin mengembalikan ajaran Islam kepada sumbernya yang murni, tidak hanya dengan pemikiran, tapi kalau perlu juga dengan senjata. Geraka ini sama sekali belum terkena sentuhan Barat; (2) Modernisme Klasik, yang muncul pertengahan abad ke-19 dan awal abad ke-20 di bawah pengaruh ideide Barat. Gerakan ini berusaha memperluas "isi" ijtihad seperti hubungan antara akal dan wahyu, pembaharuan sosial, khususnya dalam bidang pendidikan dan status wanita, serta pembaruan politik. Gerakan ini mencoba mengadopsi ide-ide Barat tanpa meninggalkan Al-Qur'an dan Sunnah (historis, bukan teknis). Sekalipun Rahman tidak menyebutkan contohnya, M. Abduh dapat kita masukkan dalam tipologi ini; (3) Neorevivalisme atau Revivalisme Pascamodernis. Gerakan ketiga ini memandang bahwa Islam itu mencakup segala aspek kehidupan manusia, oleh sebab itu tidak memerlukan ide-ide dari Barat. Gerakan ini merupakan reaksi terhadap modernisme klasik. Barangkali

${ }^{22}$ Ibid., hlm. 31. 
masuk dalam tipologi ini Al-Maududi dari Pakistan dan Hasan Al-Bana dari Mesir; (4) Neo Modernisme, gerakan yang lahir dari pengaruh neo revivalisme, tetapi sekaligus juga merupakan tantangan terhadapnya. Neo modernisme mengembangkan sikap kritis terhadap Barat maupun terhadap warisan kesejarahan Islam sendiri. Untuk itu harus dirumuskan metodologi pemahaman doktrin-doktrin Islam yang kontekstual atau historis. Rahman menganggap dirinya sebagai pelopor gerakan ini. ${ }^{23}$

Meminjam tipologi Rahman di atas, gerakan pembaruan Islam di Indonesia yang muncul akhir abad ke-19 dan awal abad ke-20 seperti Sumatera Thawalib di Minangkabau, Muhammadiyah dan Al-Irsyad di Jawa, dan lain-lain yang sejenis dapat dimasukkan dalam tipologi kedua (modernisme klasik), sekalipun pengaruh tipologi pertama (revivalisme pramodernis) sangat kuat terhadap gerakan-gerakan pembaruan tersebut. $^{24}$

Gerakan ketiga dan keempat baru tampak pengaruhnya di Indonesia sejak tahun 1980an. Pengaruh Neo Revivalisme tampak pada gerakan-gerakan Islam Kampus (terutama yang berpusat di Masjid Salman, Bandung; Arif Rahman Hakim, Jakarta; dan Jama'ah Shalahuddin, Yogyakarta), sedangkan pengaruh Neo Modernisme tampak pada gerakan pembaruan Nurcholish Madjid dengan Paramadinanya di Jakarta. Lalu ke dalam tipologi mana pemikiran Reaktualisasi Munawir dimasukkan?

Penulis merasa kesulitan memasukkan Munawir ke dalam salah satu tipologi di atas, karena di satu sisi Munawir bersikap kritis terhadap warisan kesejarahan Islam, seperti Neo Modernisme, tapi tidak terlihat bersikap kritis terhadap Barat, sebagaimana ciri lain Neo Modernisme, bahkan Munawir tidak membicarakannya. Tapi dari segi metode menafsirkan Al-Qur'an, tampaknya Munawir sama --kalau tidak dikatakan mengikuti-- Rahman. Menurut Rahman, untuk memahami pesan Al-Qur'an sebagai suatu kesatuan haruslah mempelajarinya

${ }^{23}$ Taufik Adnan Amal (ed.), Metode dan Alternatif Neo Modernisme Islam Faẓlur Rabman (Bandung: Mizan, 1987), hlm. 17-20.

${ }^{24}$ Lihat Fachry Ali dan Bakhtiar Effendi, Merambah Jalan Baru Islam, Rekonstruksi Pemikiran Islam Indonesia Masa Orde Baru (Bandung: Mizan, 1986), hlm. 62-67; Burhanuddin Daya, Gerakan Pembaharuan Pemikiran Islam Kasus Sumatera Thawalib, cet. i (Yogyakarta: Tiara Wacana, 1990). 
dengan sebuah latar belakang, baik latar belakang langsung berupa aktivitas Nabi sendiri dan perjuangannya selama kurang lebih 23 tahun di bawah bimbingan Al-Qur'an, maupun latar belakang tidak langsung yaitu pandangan hidup orang-orang Arab sebelum atau sesudah Islam datang, adat istiadat, pranata-pranata sosial, kehidupan ekonomi dan hubungan-hubungan politik mereka, terutama peran penting suku Quraisy—suku yang sangat kuat, dan Nabi berasal darinya-dan pengaruh kekuasaan religio-ekonominya di kalangan orang-orang Arab. Tanpa memahami hal-hal ini, menurut Rahman, usaha untuk memahami pesan Al-Qur'an secara utuh merupakan suatu pekerjaan yang sia-sia. ${ }^{25}$ Barangkali Munawir sedang berada dalam perjalanan dari Modernisme Klasik menuju Neo Modernisme.

\section{G. Penutup}

Masih sulit menilai sejauhmana pengaruh pemikiran reaktualisasi Munawir terhadap perkembangan pemikiran Islam di Indonesia, karena memang kemunculan gagasan tersebut belum lama dan masih dalam proses sampai hari ini. Tetapi sebagai gambaran sikap dapat dilihat bahwa keresahan Munawir terhadap sikap mendua umat Islam Indonesia dalam masalah bunga bank dijawab dengan mendirikan Bank Muamalat Indonesia, disusul oleh Bank Perkreditan Rakyat Syari'ah dan Baitul Mal wa-Tamwil, dan belakangan muncul beberapa bank Syari'ah lainnya seperti BNI Syari'ah, Bank Syari'ah Mandiri, dan BRI Syari'ah. Diikuti juga dengan munculnya asuransi Syari'ah dan reksadana Syari'ah.

Sementara itu persoalan warisan, bagaimana pengaruhnya harus diteliti kembali, paling tidak dalam kasus-kasus yang dibawa ke Pengadilan Agama di Kalimantan Selatan dan Sulawesi Selatan, yang kasus-kasus di wilayah tersebut yang menjadi salah satu faktor yang mendorong lahirnya pemikiran reaktualisasi dalam hukum warisan.

Bagaimana pun pengaruhnya, yang pasti gagasan reaktualisasi ajaran Islam yang dilontarkan Munawir dapat merangsang aktivitas intelektual di Indonesia, khususnya dalam bidang studi Islam. Dengan demikian, artikulasi keislaman kaum muslim Indonesia akan lebih relevan dengan situasi lokal dan temporal Indonesia.

${ }^{25}$ Taufik Adnan Amal (ed.), Metode dan Alternatif, hlm. 55-56. 


\section{BIBLIOGRAFI}

Abdul Hakim, Sudarnoto, dkk. (peny.), Islam Berbagai Perspektif Didedikasikan untuk 70 Tahun Prof. Dr. H. Munawir Sjadzali, M.A, Yogyakarta : LPMI, 1995.

Ali, Fachry dan Bakhtiar Effendi, Merambah Jalan Baru Islam, Rekonstruksi Pemikiran Islam Indonesia Masa Orde Baru, Mizan: Bandung, 1990. Amal, Taufik Adnan (ed.), Metode dan Alternatif Neomodernisme Islam Fą̊ur Rabman, Bandung: Mizan, 1987.

Azhar, Muhammad, "Kajian terhadap Berbagai Konsepsi Pemikiran Islam di Indonesia”, Makalah Seminar Kelas Pascasarjana IAIN Sunan Kalijaga Yogyakarta, t.t.

Baltaji, Muhammad, Manhaj 'Umar ibn al-Khatțäb fi'l-Tasyr', cet. ii, Kairo: Dār al-Salām, 2003.

Daya, Burhanuddin, Gerakan Pembaharuan Pemikiran Islam Kasus Sumatera Thawalib, cet. i, Yogyakarta: Tiara Wacana, 1990.

Husaini, Adian. Nurcholish Madjid Kontroversi Kematian dan Pemikirannya, cet. i, Jakarta: Khairul Bayan Press, 2005.

Kurzman, Charles, Liberal Islam, cet. i, New York: Oxford University Press, 1998.

Nafis, Muhammad Wahyuni, dkk. (ed.), Kontekstualisasi Ajaran Islam, 70 Tahun Prof. Dr. H. Munawir Sjadzali, MA, Jakarta: Paramadina, 1995.

Rakhmat, Jalaluddin, dkk., Tharikat Nurcholishy Jejak Pemikiran dan Pembaharuan sampai Guru Bangsa, cet. i, Yogyakarta: Pustaka Pelajar, 2002.

Saimima, Iqbal Abdurrauf (ed.), Polemik Reaktualisasi Ajaran Islam, Jakarta: Pustaka Panjimas, 1988.

Santosa, Iqbal, "Prof. Dr. Munawir Sjadzali, M.A: Hidup yang tak Terbayangkan", PERTA, Jurnal Komunikasi Perguruan Tinggi Islam, No. 2/Vol. III/2000.

Sjadzali, Munawir, Islam dan Tata Negara, Ajaran, Sejarah dan Pemikiran, cet. i, Jakarta: UII Press, 1990. 
Yunahar Ilyas

—, Muslims Interest are Better Served in the Absence of Muslim Parties, Jakarta: Departemen Agama, 1992.

—, Ijtihad Kemanusiaan, Jakarta: Paramadina, 1997. 